\title{
Corporations and Human Rights Obligations
}

\author{
Denis G ARNOLD*
}

\begin{abstract}
The claim that corporations have human rights obligations remains contentious and can be fraught with confusion. This article synthesizes existing corporate human rights theory and responds to objections to the idea that transnational corporations (TNCs) have human rights obligations. The argument proceeds in three stages. The first section describes the different forms TNCs take and explains why TNCs are properly understood as moral agents responsible for their policies and practices. The second section reviews and explains different philosophical theories of corporate human rights obligations. The third section articulates and responds to objections to the idea that corporations have human rights obligations. The main conclusion of this article is that there are multiple, compelling and overlapping justifications of corporate human rights obligations.
\end{abstract}

Keywords: corporate ontology, corporate moral agency, human rights obligations, corporate social responsibility, international business ethics

The new corporate human rights agenda has become institutionalized via the adoption and dissemination of the voluntary United Nations 'Protect, Respect and Remedy' Framework. However, the claim that corporations have human rights obligations remains contentious and can be fraught with confusion. The aim of this article is to synthesize existing corporate human rights theory and respond to objections to the idea that transnational corporations (TNCs) have human rights obligations. The arguments of this article may be read as a primer in philosophical human rights theory as applied to corporations. We proceed in three stages. First, because it is sometimes claimed that corporations are not the sort of entity that can have human rights obligations the first section describes the different forms TNCs take and explains why TNCs are properly understood as intentional organizations that are morally responsible for their policies and practices. The second section takes up the question of human rights obligations directly by reviewing and explaining different theories of corporate human rights obligations. The third section articulates and responds to objections to the idea that corporations have human rights obligations. The main conclusion of this article is that there are multiple, compelling and overlapping justifications of corporate human rights obligations.

\footnotetext{
* Jule and Marguerite Surtman Distinguished Professor of Business Ethics and Professor of Management, Belk College of Business, University of North Carolina at Charlotte; Editor in Chief, Business Ethics Quarterly (2011-2016) [denisarnold@uncc.edu].

Thanks to Florian Wettstein and Wesley Cragg for helpful written comments on earlier drafts. I am grateful to the Surtman Foundation for financial support of this research.
} 


\section{Corporate Moral Agency}

How can TNCs have moral obligations, in addition to legal obligations? In what sense can TNCs be said to have moral responsibility, in addition to legal culpability? To answer these questions, we need to examine the ontological status of corporations. A common refrain in much management, finance, and economics literature, and some legal scholarship, is that TNCs are mere legal fictions established for the purpose of enhancing the economic interests of investors and do not possess the agency necessary to be duty bearers. But as we shall see, there are good reasons for thinking that this view is mistaken. While there are compelling reasons for claiming that corporations are moral agents, ${ }^{1}$ that position remains contentious. ${ }^{2}$ The aim of this section is to explain why TNCs are properly understood to have the ontological status necessary to be duty bearers that are morally, and not just legally, responsible for corporate policies and practices. It is important to clarify from the outset that the position defended in this article is not that corporations are 'moral persons', as nearly all scholars of corporate ontology deny that corporations are persons and have done so for at least 20 years-ever since the leading proponent of that view, Peter French, repudiated the idea that ontologically corporations are 'moral persons' and modified his view to one in which corporations are properly understood as 'moral agents'. ${ }^{3}$ The aim of this section, then, is to explain the idea of corporate moral agency as applied to TNCs. ${ }^{4}$

\section{A. Forms of TNCs}

To begin, let us consider the corporate form. A variety of types and sizes of companies operate internationally. Small or medium sized firms may have supply chains that extend across national boundaries, or may service foreign customers, but are based in one nation. Larger organizations that have operations and employees in many nations are the primary subject of analysis in this article. Bartlett and Ghoshal provide a conceptual framework for understanding the different types of organizational structures of large firms operating in an international context. ${ }^{5}$ In recent history, they argue, there have been three main types of organizational structures. First, there are multinational companies characterized by a decentralized governance structure with self-sufficient companies operating in host nations. The strategy of multinational companies is based on sensitivity and responsiveness to national contexts, and knowledge acquired and retained within national units. Second, there are global companies that are characterized by the centralized governance of a parent

\footnotetext{
1 Thomas Donaldson, Corporations and Morality (Englewood Cliffs: NJ: Prentice-Hall, 1982); Peter A French, 'Integrity, Intentions, and Corporations' (1996) 34:2 American Business Law Journal 141-56; Denis G Arnold, 'Corporate Moral Agency' (2006) 30 Midwest Studies in Philosophy 279-91.

2 Amy J Sepinwall, 'Denying Corporate Rights and Punishing Corporate Wrongs' (2015) 24:4 Business Ethics Quarterly 517-34.

3 French, note 1; Arnold, note 1.

4 Discussions of the ontological status of corporations and moral responsibility are distinct from discussions of the legally granted artificial personhood that allow the corporation to be legally distinct from its shareholders and to have certain legal rights such as property ownership. In the U.S., corporations have been recognized as legal persons since the Supreme Court's decision in Santa Clara County v Southern Pacific Railroad Company, 118 U.S. 394, 397 (1886). For a discussion of the current legal status of corporate persons, including corporate rights, see Margaret M Blair, 'Of Corporations, Courts, Personhood, and Morality' (2015) 25:4 Business Ethics Quarterly 415-31.

5 Christopher A Bartlett and Sumantra Ghoshal, Managing across Borders: The Transnational Solution, $2^{\text {nd }}$ edn. (Cambridge: Harvard Business School Press, 2002).
} 
company operating from a home nation. The strategy of global companies is characterized by the efficient deployment of a uniform strategy in host-nations, and knowledge acquired and retained by the centre. Finally, there are international companies that are characterized by a combination of centralized and decentralized core competencies. International companies utilize a strategy of leveraging parent company competencies grounded in knowledge acquired centrally and distributed overseas. ${ }^{6}$

Bartlett and Ghoshal argue that in order for modern, transnational companies to adapt to a global marketplace and remain competitive they need to be responsive to national contexts, efficient in their global operations, and capable of leveraging parent company competencies. That is, they argue that companies need to adapt key attributes from each of the three types of companies operating globally in order to be economically successful. In this article the phrase 'transnational corporations' is utilized to encompass multinational companies, global companies, and international companies, as well as the model of transnational companies that Bartlett and Ghoshal advise general managers to adapt. Each type of company is transnational in the sense that the scope of company operations, customer base, or supply chains extend across national boundaries and often into regulatory and governance gaps. While characteristics described by Bartlett and Ghoshal are important for understanding the differences between the varieties of companies operating internationally, and the strategic advantages and disadvantages of each variety, the differences are insignificant for clarifying the human rights and other obligations of businesses.

Each type of company described by Bartlett and Ghoshal directs the behaviour and operations of subsidiaries in host nations. Multinational companies may grant more autonomy to subsidiary companies than global companies, but each type of company has the ability to direct subsidiary operations via an internal decision structure and a transnational ethical infrastructure. The internal decision structure includes hierarchical lines of organizational responsibility, rules of procedure, and corporate policies. ${ }^{7}$ The ethical infrastructure of a company includes corporate ethics and compliance managers, employee training, company values statements, employee assessment and incentives linked to policies and values, and communications about ethics and compliance. ${ }^{8}$ The existence of internal decision structures and ethical infrastructures helps us to understand how companies can exhibit intentionality ${ }^{9}$ and why it is reasonable to hold both companies and their executive leadership teams accountable for organizational behaviour including ethical transgressions. We refer to corporate moral agents, to delineate moral agents with internal decision structures comprised of human persons from other types of moral agents.

Intentionality, in the sense relevant here, is understood as the ability to plan future actions in a coordinated manner. ${ }^{10}$ More specifically, plans have two distinct

6 Ibid, 16-18.

7 Peter A French, 'The Corporation as a Moral Person' (1979) 16:3 American Philosophical Quarterly 207-15.

8 Ann E Tenbrunsel, Kristin Smith-Crowe and Elizabeth E Umphress, 'Building Houses on Rocks: The Role of the Ethical Infrastructure in Organizations' (2003) 16:3 Social Justice Research 285-307; Linda K Treviño and Katherine A Nelson, Managing Business Ethics (New York: John Wiley \& Sons, 2010).

9 French, note 1; Arnold, note 1.

10 Michael Bratman, Intention, Plans, and Practical Reason (Cambridge: Harvard University Press, 1987); and Michael Bratman, Faces of Intention: Selected Essays on Intention and Agency (Cambridge: Harvard University Press, 1999). 
features: 1) they are typically partial or incomplete and need to be filled in over time; 2) plans typically have a hierarchical structure in which some plans are embedded in other plans. This type of intentionality exists at the individual, group, and organizational level, but at the group and organizational level planning is accompanied by coordination. Understanding how organizations such as companies exhibit intentionality is important for understanding claims regarding corporate moral agency and organizational normative legitimacy.

\section{B. Corporate Intentionality}

Before explaining how companies exhibit intentionality, it will be helpful to illustrate the planning conception of intentionality at the individual and group levels. At the individual level, imagine that a manager takes an overseas business trip. She must formulate a plan that will get her there and act upon it with the support of her assistant. Formulating the plan will involve reflection and deliberation on the length of her stay, appropriate travel dates, appropriate flights, and so on. However, some things will be left open, such as how she will travel to the airport and where she will eat while overseas. Acting on her plan will involve making airline reservations, traveling to the airport, obtaining a visa, and so on. As the time of travel draws closer, other aspects of the plan will be filled in based on current information and prior adjustments to the plan.

Similar planning takes place by groups. To see this, imagine the manager is one of several business associates, all of whom live in different cities, who agree to travel to China to tour the operations of a potential new supplier. A mutual intention to travel comes into existence once all parties come to this decision. The associates coordinate their sub-plans to facilitate the end of evaluating the potential supplier. Each person is aware of the sub-plans of other members of the group necessary for the execution of the plan. The required level of knowledge will vary between individuals and further plans, such as how many cities they visit, may still need to be negotiated. These negotiations regarding sub-plans may continue after the group has begun to carry out their plan. If the group satisfies the criteria of intentionality in these ways, it is proper to say that it has a collective intention to travel to China to evaluate a potential new supplier. ${ }^{11}$

Now consider this conception of intentionality as it applies to corporations and other organizations. TNCs routinely utilize planning, along with analysis, and assessment, to achieve strategic goals that allow them to remain competitive and provide value to their customers. Long term planning is an important component of strategic management and is routinely taught in business schools. Consider the example of a company implementing a new anti-corruption program in all of its global operations. Bribery anywhere in the world is illegal for all companies conducting business in the United States under the Foreign Corrupt Practices Act and in the United Kingdom under the Bribery Act (consistent with the OECD Convention on Combating Bribery of Foreign Officials in International Bribery Transactions). Utilizing the ability of TNCs to adhere to legal regulations is helpful because it illustrates how companies can and do meet one type of obligation: namely the obligation to obey the law. The orthodox view of the

11 Arnold, note 1, 285-8. 
purpose of the firm holds that the function of executives and managers is to maximize economic value for firm owners while adhering to the law. However, almost no management, finance, or economics scholars explicitly defend the idea that companies should violate the law in the interest of additional wealth creation. Conventions and laws make bribery illegal because bribery is widely understood to undermine economic development, human rights, and democracy. Transparency International, the respected anti-corruption organization, succinctly summarizes the reasons that bribery has been made illegal via regulations and conventions.

Corruption impedes investment, undermines economic growth, diverts humanitarian assistance and reduces market opportunities for legitimate business. When government is for sale, it destroys public trust in democratic institutions and denies citizens, businesses, taxpayers, and consumers the benefit of open markets and fair competition. Corruption disproportionately burdens the poor, diverting scarce resources that could otherwise help lift millions out of poverty. It raises the costs of education, nutrition, clean water, and health care, often denying citizens these essential public services. ${ }^{12}$

Bribery is also related to human rights. As Mary Robinson has noted, 'When individuals and families have to pay bribes to access food, housing, property, education, jobs and the right to participate in the cultural life of a community, basic human rights are clearly violated.' 13

How might a TNC intentionally implement an anti-corruption policy? Such a process might look like the following: First, executives form a committee to oversee this process. The committee might include the company's chief ethics officer and representatives from the general counsel's office, internal auditing, human resources, and representatives from divisions operating in nations with high levels of corruption. Coordination is accomplished in the different departments and divisions of the company and its subsidiaries. For example, the corporate ethics office develops the principles and practices that will guide company behaviour, the training of employees, and coordinates the production of an antibribery handbook that describes various scenarios and appropriate responses in each of the nations or regions in which the company operates. Human resources crafts disciplinary procedures for employees who violate the policy. Corporate communications ensures that all employees are informed of the anti-bribery policy, together with sanctions for violations, and so on. The coordination requirement is satisfied insofar as each person is aware of the sub-plans of other members of the group necessary for the execution of the plan. Again, the required level of knowledge will vary between individuals. Presumably each employee of the company will need to be made aware of both the anti-bribery policy, and the corresponding disciplinary policy. Further plans may still need to be negotiated, such as incentives to help convince employees to comply with the new policy and appropriate responses for non-compliance. These negotiations regarding sub-plans may continue after the group has begun to carry out their plan. If the criteria of intentionality are met in these ways, it is proper to say that the company has a collective intention to create and institute a new anti-bribery program.

\footnotetext{
12 Transparency International, 'Mission and History', http://www.transparency-usa.org/archive/who/mission.html (accessed 17 October 2015).

13 Transparency International, Global Corruption Report (London: Pluto Press, 2004) 7.
} 
It might be argued that multinational companies, where subsidiaries exhibit more autonomy, would find the process of implementing a global anti-corruption policy more challenging than global companies because parent companies in multinationals exhibit less control than global companies where parent companies retain greater control. However, multinational companies have the advantage over global companies of deep knowledge of local contexts that may better facilitate education and training of subsidiary employees relative to the local context of corruption. In other words, both types of companies have strengths and weaknesses with regard to implementing standards globally. Transnational companies that are both responsive to national contexts and capable of leveraging parent company expertise in training, evaluation, monitoring, and enforcement of employee compliance with anti-corruption policies may have an advantage in the successful implementation of anti-corruption policies. However, each of the company structures in Bartlett and Ghoshal's typology is compatible with the development and implementation of corporate ethics policies.

It is because the implementation of company policies and practices are intentional in the way that has been described here that it is proper to hold companies and their leaders morally responsible for corporate activity. However, in addition to intentionality and an internal decision structure, a further condition must be met if corporations are to be regarded as agents that are morally responsible for practices and policies independently of individual directors, executives, and employees. Corporations must be capable of reflectively endorsing or rejecting existing practices and strategies. Corporations that are capable of evaluating past decisions and existing practices, of determining whether those corporate intentions ought to remain in place, or whether they should be modified or eliminated in favour of alternative plans and strategies, are capable of the requisite reflective decision making and are properly understood as moral agents.

To illustrate the account of moral agency described here consider the example of Walmart's alleged use of bribery in Mexico. Walmart de Mexico, the Walmart subsidiary in Mexico, allegedly used large payoffs made to governmental officials to circumvent the law and obtain permits to build its stores in culturally and environmentally sensitive locations. ${ }^{14}$ It is estimated to have spent at least US\$24 million on illegal bribes in an effort to grow faster and bigger than its competition while using fraudulent accounting to cover up the bribes. Walmart did this in a systematic and entrepreneurial manner, seeking out officials it could bribe rather than succumbing to extortion by already corrupt officials. When these activities were reported to Walmart headquarters, an initial investigation by its internal investigations team was undertaken, but was then stopped by senior executives. The executive in charge of Walmart de Mexico, identified in media reports as the influential force behind the bribery scheme, was promoted to vice chairman of Wal-Mart. The company did not self-disclose the illegal activity to the U.S. Department of Justice until news reporters

\footnotetext{
14 The account of Walmart's alleged actions in this section is based on the Pulitzer Prize winning investigative reporting of David Barstow and Alejandra Xanic von Bertrab. The U.S. Department of Justice has not yet determined Walmart's culpability. However, regardless of its accuracy the account presented by Barstow and von Bertrab can be used to illustrate the account of corporate agency that is our concern here. See David Barstow, 'Vast Mexico Bribery Case Hushed up by Wal-Mart after Top-Level Struggle', The New York Times (22 April 2012), A1; David Barstow and A Xanic von Bertrab (2012). 'The Bribery Aisle: How Wal-Mart Got its Way in Mexico', The New York Times (18 December 2012), A1.
} 
investigated the allegations. In response, Walmart was widely criticized by Mexican social justice advocates, institutional investors, corporate governance authorities, and nongovernmental organizations. A different bribery scheme was later discovered in Walmart's Indian operations. The failure of the parent company to monitor and enforce its own anti-bribery policies at Walmart de Mexico, or to discipline those involved, further undermined Walmart's normative legitimacy which has already been undermined by its labour practices in the U.S. and in its global supply chains.

The Business Principles for Countering Bribery provide comprehensive guidance for TNCs seeking to implement strong compliance with international anti-bribery regulations. ${ }^{15}$ Many firms utilize these principles to combat bribery in their global operations. Criticism of Walmart is appropriate because Walmart de Mexico appears to have intentionally engaged in bribery as a strategy to gain competitive advantage in Mexico; the U.S. parent company failed to put in place controls to prevent bribery by its subsidiary and instead rewarded the executive that oversaw the bribery scheme; and because Walmart failed to address the problem internally or report the illegal activity to U.S. or Mexican authorities when it was first discovered. Corporate intentionality for illegal behaviour, as illustrated in this example, is utilized by governmental authorities for assessing culpability and determining appropriate sanctions for illegal activity. For example, it is utilized by U.S. attorneys and judges to determine culpability and penalties under the Federal Sentencing Guidelines for Organizations.

After the bribery scheme was made public, Walmart promptly implemented a new plan for its global ethics and compliance programs. This included increasing its compliance staff by 30 per cent and requiring that potential foreign corruption be reported to global corporate headquarters and the board of directors. ${ }^{16}$ This is an example of the reflective assessment of existing practices and the implementation of new plans that is a necessary condition of agency. It illustrates a typical example of organizational change, one that is grounded in a recognition that some external control agents are unwilling to tolerate misconduct and a recognition that maintaining organizational legitimacy requires that the firm alter its current practices and implement new plans.

Meeting human rights obligations can be understood as a central element of the ethics and compliance programs of TNCs, just as implementing anticorruption programs are for many companies. It might be thought that because TNCs have human rights obligations, they should also be understood as rights bearers. ${ }^{17}$ Agency is not, however, a sufficient condition for personhood. As explained in the following section, persons in the ontological (not legal) sense have freedom of the will, the capacity to gain meaning, personal satisfaction, and happiness, from the pursuit of plans and life projects, and the moral status of ends in themselves. These characteristics are not shared by corporations,

\footnotetext{
15 David Hess, 'Partnering against Corruption Initiative and the Business Principles for Countering Bribery' in Thomas Hale and David Held (eds.), The Handbook of Transnational Governance: Institutions and Innovations (Cambridge: Polity Press, 2011) 322-7.

16 Elizabeth A Harris, 'After Bribery Scandal, High-Level Departures at Walmart', The New York Times (5 June 2014) B1.

17 John D Bishop, 'The Limits of Corporate Human Rights Obligations and the Rights of for-Profit Corporations' (2012) 22:1 Business Ethics Quarterly 119-44.
} 
but these characteristics are essential features of moral justifications of human rights. ${ }^{18}$ This unique status of human persons is recognized in the Universal Declaration of Human Rights which is explicitly grounded in the 'dignity and worth of the human person' and which makes repeated use of the concept of human dignity. Mere agents, in contrast, possess none of these qualities. For example, a sophisticated computer that exhibited agency but did not have freedom of the will, nor the capacity to gain meaning, personal satisfaction, and happiness, from the pursuit of plans and life projects, would not qualify as a person entitled to human rights, even if it was granted the status of legal personhood.

To sum up, TNCs are properly understood as corporate moral agents capable of being duty bearers and entities morally responsible for their actions because they have internal decision structures comprised of human agents, including the ethical infrastructure of the firm, corporate intentions understood primarily as plans, and the capacity for reflective assessment of corporate plans and practices.

\section{Corporate Human Rights Obligations}

There are a variety of ways of conceptualizing corporate human rights obligations, and different ways of thinking about human rights naturally entail different sets of human rights obligations. Much of the apparent disagreement regarding corporate human rights obligations reflects differences in the types of rights at issue and in the way scholars conceptualize the responsibilities of corporations to preserve or promote justice. Unpacking these distinctions will go some way toward providing clarity regarding corporate human rights obligations.

In the broader academic literature and international discourse on rights, many different types of rights are discussed including natural rights, moral rights, political rights, human rights, and legal rights. There is often an overlap between such rights, as for example between rights claimed to be natural or moral in nature which are also legally protected by states. Many of these rights are properly encompassed under the broader category of claim rights. Claim rights entitle individuals to assistance from other parties in the form of protection against injury or death, the provision of help in cases of need, the performance of responsibilities previously agreed upon or legally required, or to compensation from harm caused. ${ }^{19}$

18 These characteristics of human persons are explained in detail in Section II. A. below. Amy Sepinwall (note 2, 523-44) uses human rights theory to argue against the idea that corporate moral agency is philosophically distinct from corporate moral personhood, and thereby susceptible to the criticisms levelled against corporate moral personhood. However, in doing so she ignores each of these features of moral accounts of human rights. It is only because she ignores these essential features of moral accounts of human rights that her use of human rights theory to deny the possibility of a distinction between agency and personhood may seem plausible. But the account of human rights theory she presents is partial and incomplete. Once this mistake is recognized and a full account is provided, her argument for denying the distinction fails. Nonetheless, she provides pragmatic moral and political reasons for thinking that corporations should be regarded as morally and legally responsible agents that are compatible with the ontological argument provided here.

19 For the classic analysis of right as claims see Joel Feinberg, 'Duties, Rights, and Claims' (1966) 3:2 American Philosophical Quarterly 137-44; see also Denis G Arnold, Robert Audi and Matt Zwolinski, 'Recent Work in Ethical Theory and its Implications for Business Ethics' (2010) 20:4 Business Ethics Quarterly 559-581; Charles R Beitz, The Idea of Human Rights (New York: Oxford University Press, 2009); Leif Wenar, 'The Nature of Rights' (2005) 33:3 Philosophy \& Public Affairs 223-52. Wenar defends a framework for understanding the nature of all rights that is divided into four basic types and two categories. The two categories are first-order rights over one's mind and body and second-order rights over first-order rights. The four types of rights are privileges, claims, powers and immunities. 
The parties who have a responsibility to satisfy the claim rights are said to have duties or obligations to the rights holder. Human rights are typically examples of claim rights, but human rights can be conceptualized in different ways. In some cases different conceptualizations of human rights are compatible, in other cases they are not. An employee's right to be free from corporal punishment, to compensation consistent with the satisfaction of basic needs, and to be paid according to the terms of his or her contract are examples of claim rights. But who is the duty bearer in these cases? Is it the state in which the corporation operates? Is it the corporation? Or is it some other entity such as global governance institutions? The answer to these questions depends upon both the way in which human rights are conceptualized and the way in which corporate human rights obligations are understood. Broadly construed, conceptual analysis of human rights may be divided into two primary categories: moral rights and political rights. Both of these types of analysis can be influential in determining which rights are given legal protection. Let us consider each in turn.

\section{A. Human Rights as Moral Rights}

Moral rights are most often grounded in considerations regarding the nature of humanity. Here the central concern focuses on what is required to live a functional human life given that humans are self-governing beings, physically vulnerable and susceptible to harm, and with basic needs such as adequate food, water, and shelter. The most common accounts of the moral basis of human rights developed by philosophers over the last 30 years have emphasized the centrality and importance of autonomy or agency. There are two, compatible ways in which this basis for moral rights has been defended. First, the intrinsic account, which has a lineage that extends to Kant, emphasizes that selfgoverning beings possess a unique dignity that rights serve to protect. ${ }^{20}$ On this account, rights confer the moral status of inviolability that is independent of the general good of society. ${ }^{21}$ Rights are not moral goods in need of our protection merely because of the ends they allow persons to achieve, rather rights are moral goods that should be protected because they confer upon persons the status of ends in themselves. As such, when a person's rights are violated a wrong has been committed regardless of other considerations. Second, an instrumental account of human rights is concerned with the ability of people to pursue practical interests and long term projects in the interest of achieving happiness, satisfaction, or meaning. ${ }^{22}$ Here the argument is that to achieve a fulfilling human life, rights need to be protected. On an instrumental account rights are derivative of other values, such as the goods of happiness, freedom, or self-realization. ${ }^{23}$ In the case of both accounts of moral human rights presented here, it is proper to ascribe responsibility, and potentially blame, to individuals, organizations, or institutions that violate the rights of individuals.

\footnotetext{
20 Immanuel Kant, Foundations of the Metaphysics of Morals (New York: Macmillan, 1990 (1785)); Thomas Nagel, 'Personal Rights and Public Space' (1995) 24:2 Philosophy \& Public Affairs 83-107; Robert Nozick, Anarchy, State, and Utopia (New York: Basic Books, 1974); and Alan Gewirth, Human Rights: Essays on Justification and Applications (Chicago: University of Chicago Press, 1982).

21 Nagel, note 20, 25.

22 James Griffin, On Human Rights (New York: Oxford University Press, 2008); Loren E Lomasky, Persons, Rights, and the Moral Community (New York: Oxford University Press, 1987).

23 Nagel, note 20,86 .
} 
I have previously argued that agentic accounts of human rights provide an appropriately deep foundation for corporate human rights obligations, particularly when limited in scope to basic rights such as liberty, physical security, and subsistence. ${ }^{24}$ Basic rights are those rights that are necessary for the attainment of other rights; they are rights required for a decent human life. ${ }^{25}$ Basic rights take the form of side-constraints that bound the moral space in which corporations may legitimately pursue economic ends. Basic human rights obligations for corporations include ensuring that workers are not subject to forced labour, human trafficking, corporal punishment, imprisonment, discrimination, suppression of their freedom to organize, or death or injury resulting from poor safety standards. It might also mean that local communities are not exposed to harmful pollutants and that the natural environment is not so adversely impacted as to undermine health or the utilization of natural resources for economic and physical subsistence. Putting the issue in the form of an interrogative can help to provide focus and clarity: If an agentic account of human rights is correct, how could managers of companies, or their agents, be exempt from meeting the obligation not to violate the human rights of individuals with whom they interact or impact in their operations? The fact that corporations are legal entities with proscribed economic aims and legal protections makes it challenging to hold firms legally liable for human rights violations, especially in nations with significant governance gaps, but this does not alter the force of morally grounded human rights obligations. ${ }^{26}$ Since TNCs are moral agents that have specific relationships with employees, contractors, customers, and the individual members of communities in which they operate, those individuals with whom they have relationships, or upon whom they have a direct impact (e.g., via water or air pollution) have legitimate claims on TNCs to meet basic human rights duties.

Finally, to conclude our review of morally grounded human rights obligations for corporations, we will consider the social contract model defended by Thomas Donaldson and Wesley Cragg. ${ }^{27}$ This model is distinct from, but compatible with, agentically grounded corporate human rights obligations. A unique feature of this analysis is that it is entirely focused on corporations and not derivative of more general theories of human rights. Cragg's version of the social contract theory of corporate human rights obligations begins with the historically grounded claim that the legal status of corporations is expressly designed to promote public goods and that the legal status of corporations is fluid, rather than static, adapting as it has historically to societal changes. Cragg argues that when a need arises to 'rearticulate and reallocate responsibilities for

\footnotetext{
24 Denis G Arnold, 'Transnational Corporations and the Duty to Respect Basic Human Rights' (2010) 20:3 Business Ethics Quarterly 371-99; Denis G Arnold, 'Global Justice and International Business' (2013) 32:1 Business Ethics Quarterly 125-43; Denis G Arnold and Andrew Valentin, 'CSR at the Base of the Pyramid: Exploitation, Empowerment, and Poverty Alleviation’ (2013) 66:10 Journal of Business Research 1904-14.

25 Henry Shue, Basic Rights: Subsistence, Affluence, and U.S. Foreign Policy, $2^{\text {nd }}$ edn. (Princeton, NJ: Princeton University Press, 1996).

26 Peter T Muchlinski, Multinational Enterprises and the Law (Oxford: Oxford University Press, 2007) 507-36.

27 Wesley Cragg, 'Human Rights, Globalisation and the Modern Stakeholder Corporation' in Tom Campbell and Seumas Miller (eds.), Human rights and the Moral Responsibilities of Corporate and Public Sector Organisations (Dordrecht: Kluwer Academic Publishers, 2004); Wesley Cragg, 'Business and Human Rights: A Principle and Value Based Analysis' in George Brenkert and Tom Beauchamp (eds.), The Oxford Handbook of Business Ethics (New York: Oxford University Press, 2009); Thomas Donaldson, The Ethics of International Business (Oxford: Oxford University Press, 1991).
} 
ensuring that public expectations of reciprocal benefits is realised', such a reallocation is warranted to ensure the public interest and provide ongoing normative legitimacy for the corporate entity. ${ }^{28} \mathrm{He}$ then points to the new, multi-actor model of economic globalization with its attendant governance gaps to explain how 'under conditions of globalisation, respect for and a commitment to advance respect for human rights is both constitutive of the public good to which corporations have an obligation to contribute and empirically necessary if public goods are to result from commercial corporate activity in global markets'. ${ }^{29}$ On this account, the normative legitimacy of the modern corporate form is predicated on the willingness of corporations and their managers to respect human rights in their global operations. A social contract model can be read as supplementing or overlapping with agentically grounded human rights arguments. In other words, the view are not mutually exclusive but provide compatible forms of justification for corporate human rights obligations.

\section{B. Human Rights as Political Rights}

As we have seen, both agentically grounded and social contract models provide a moral grounding for corporate human rights obligations. Political accounts of human rights, on the other hand, eschew moral justifications and instead appeal to the role rights play in the international political sphere. ${ }^{30}$ Political accounts of human rights focus on theoretical or actual agreements among nations (or 'peoples' in Rawls idiosyncratic theory) and supranational organizations such as the United Nations and the International Labour Organization. The historical function of international human rights law has been to provide universal standards for the treatment of individuals by national governments. In practice, the current international human rights legal system includes, at a minimum, the Universal Declaration of Human Rights; the International Covenant on Economic, Social and Cultural Rights; the International Covenant on Civil and Political Rights; and the International Labour Conventions. ${ }^{31}$ While moral rights may be used to justify some or all of international human rights law, international human rights can be justified independently of a direct correlation to morally justified human rights. ${ }^{32}$

While the system of international human rights emerged in the twentieth century with the explicit goal of protecting individuals against abuses by states, the system of human rights has evolved to take into account the obligations of supranational organizations

28 Cragg (2004), note 27, 124.

29 Ibid, 124.

30 Beitz, note 19; Allen E Buchanan, The Heart of Human Rights (New York: Oxford University Press, 2013); John Rawls, Law of Peoples (Cambridge, MA: Harvard University Press, 1999).

31 While the ILO Conventions are not a part of the International Bill of Human Rights, they are an important element of the international human rights legal system and are particularly important to discussions of corporate human rights obligations because employers' representatives (along with workers' representatives and government representatives) are a formal component of the ILO governance structure. The United Nations 'Protect, Respect and Remedy' Framework expressly refers to both the International Bill of Rights and the ILO Conventions.

32 Buchanan provides a compelling argument for the conclusion that the international legal system of human rights can be provided with a robust, pluralistic moral justification (that includes, among many other elements, the normative justification of the institutions and practices that create the system). Allen E Buchanan, Human Rights, Legitimacy, and the Use of Force (New York: Oxford University Press, 2009); Buchanan (2013), note 30, 14-22. 
such as corporations and multilateral organizations. As Andrew Chapman explained over 20 years ago, 'the supranational factor has meant that the individual-State dichotomy is no longer sufficient to explain complex relations in modern society ... supranational organs introduce a new power relationship with potential for abuse of power between the individual and the supranational authority'. ${ }^{33}$ While trade among nations has been an important feature of the global economy for centuries, there has been a rapid increase in international trade in recent history. Global investment outflows increased from US\$235 billion in 1990, to US\$1.15 trillion in 2000, or nearly 31 times the US\$37 billion in outflow in $1982 .{ }^{34}$ More recently outflows have increased to an annual range of US\$1.2-1.9 trillion. ${ }^{35}$ Foreign Direct Investment (FDI) can improve social welfare in developing nations through technology transfer, job creation, and economic growth. However, this substantial increase in FDI is also an important indicator of the steadily growing economic and political influence of corporations operating internationally. Transnational corporations operate in a multitude of political jurisdictions and so are subject to a multitude of legal frameworks. Laws regarding such matters as the treatment of customers, the treatment of employees, and environmental protection vary significantly in different host nations. In the case of developing economies, consumer protection, worker safety, and environmental safeguards are often poorly developed and enforced. The law enforcement infrastructure and judicial apparatus necessary to ensure compliance is often weak, understaffed, and underfunded. Transnational companies operating in such nations are often free to determine for themselves whether or not they will adhere to host nation laws.

Observers of a post-Westphalian international system note an increase in the influence and power of corporations and an inability on the part of governments to appropriately govern corporate operations and impacts. ${ }^{36}$ For example, Stephen Kobrin argues that 'the shift from a state-centric to multi-actor system associated with the emergence of a transnational world order has fragmented political authority and blurred the once distinct line between the public and private spheres: both have led to an expanded conception of the rights and duties of non-state actors'. ${ }^{37}$ It is because of actual corporate human rights abuses, and not merely the potential for such abuses, that the United Nations developed and approved the 'Protect, Respect and Remedy' Framework for Business and Human Rights and its accompanying Guiding Principles on Business and Human Rights. ${ }^{38}$

\footnotetext{
33 Andrew Clapham, Human Rights in the Private Sphere (Oxford: Clarendon Press, 1993) 138.

34 Conference on Trade and Development (UNCTAD), World Investment Report (New York/Geneva: United Nations, 2001) 2.

35 Conference on Trade and Development (UNCTAD), World Investment Report (New York/Geneva: United Nations, 2012) 16; Conference on Trade and Development (UNCTAD), World Investment Report (New York/Geneva: United Nations, 2015) 2.

36 For helpful reviews see Cragg (2009), note 27; Michael A Santoro, 'Post-Westphalia and its Discontents: Business, Globalization, and Human Rights in Political and Moral Perspective' (2010) 20:2 Business Ethics Quarterly $285-97$.

37 Stephen J Kobrin, 'Private Political Authority and Public Responsibility: Transnational Politics, Transnational Firms, and Human Rights' (2009) 19:3 Business Ethics Quarterly 353.

38 The United Nations 'Protect, Respect and Remedy' Framework, summarized by the Guiding Principles, was developed by the Special Representative of the Secretary-General on the issue of human rights and transnational corporations and other business enterprises and endorsed by the Human Rights Council in its resolution 17/4 of 16 June 2011.
} 
The Guiding Principles require that 'Business enterprises should respect human rights. This means that they should avoid infringing on the human rights of others and should address adverse human rights impacts with which they are involved' ${ }^{39}$ While not currently a legally binding set of obligations, the corporate responsibility to respect human rights enunciated in the Guiding Principles is a major development insofar as it expands the international human rights regime to include corporations and other businesses enterprises within its domain. The significance of the Guiding Principles is underscored by the failure of the earlier draft 'Norms on the Responsibilities of Transnational Corporations and Other Business Enterprises with Regard to Human Rights' to win endorsement from the United Nations. ${ }^{40}$ Peter Muchlinski has argued that the corporate responsibility to respect, and its corollary duty to undertake due diligence regarding potential human rights abuses, will eventually lead to legally binding corporate human rights obligations. ${ }^{41}$

The human rights referenced by the Guiding Principles are broader than basic moral rights, and their justification is grounded in both the legitimacy of the process by which they were determined and the political agreements that were a part of that process. These rights are compatible with moral rights, but not equivalent to morally grounded human rights. Significantly for understanding the normative legitimacy of the Guiding Principles, business organizations were active in development of the 'Protect, Respect and Remedy' Framework. The tripartite framework and the Guiding Principles were expressly endorsed by the International Organisation of Employers, the International Chamber of Commerce, and the Business and Industry Advisory Committee to the OECD. These organizations, and other business organizations and specific companies, also played a consulting role during the six-year development process of the tripartite framework. It is also important to keep in mind that employer representative have been a formal component of the ILO governance structure since its inception in 1919 and as such played a formal role in the development of the ILO conventions.

\section{Objections to Corporate Human Rights Obligations}

In this section we will consider two sorts of objections to corporate human rights obligations. These two perspectives share in common the notion that corporations are not a type of entity that can be properly regarded as having human rights obligations. As we shall see, the first perspective employs a faulty, and largely ideological, conception of the firm. The second perspective employs an inadequate and partial conception of human rights. Neither objection can withstand critical scrutiny.

\footnotetext{
39 Human Rights Council, Guiding Principles on Business and Human Rights: Implementing the United Nations “Protect, Respect and Remedy” Framework A/HRC/17/31 (21 March 2011) 13.

40 The 'Draft Norms', produced between 1999 and 2003 by the United Nations Sub-Commission on the Promotion and Protection of Human Rights, Working Group on the Methods and Activities of Transnational Corporations, were an earlier effort to establish legally binding human rights norms for corporations. For a discussion of the project and the reasons for its failure see Arnold (2010), note 24, 373-76.

41 Peter Muchlinski, 'Implementing the New UN Corporate Human Rights Framework: Implications for Corporate Law, Governance, and Regulation' (2012) 22:1 Business Ethics Quarterly 145-77.
} 


\section{A. Shareholder Primacy}

The conventional Anglo-American story regarding the normative obligations of corporate managers that is assumed in much of the economics, finance, and management literature, holds that it is the obligation of managers to maximize profits for shareholders (or private equity holders) while adhering to the law. Sometimes it is added that corporations should also avoid deception, although this is typically stipulated as an aside and not explained or defended by proponents of the 'shareholder primacy' perspective. ${ }^{42}$ Proponents of this view typically emphasize the importance of protecting property rights and the positive impact corporations have on social utility. They argue that managers who expend corporate resources on activities that are not focused on corporate profits are, in effect, undemocratically redistributing investor resources. They endorse the idea that managers are agents of shareholders who must always act on behalf of shareholder interests. A bedrock assumption upon which shareholder ideology rests is that the corporation is operating in a democratic context. It is only by assuming that citizens determine the regulatory framework of business (the 'rules of the game') that proponents of shareholder primacy and instrumental CSR have any basis for defending the idea that firms need only adhere to the law to retain normative legitimacy. ${ }^{43}$

Proponents of this view typically adhere to broadly libertarian beliefs regarding markets emphasizing minimal regulations, private property rights, freedom, especially the freedom to enter into contracts, weak labour protections, and free trade among nations. The ideological bedfellow of the shareholder primacy view is the instrumental theory of corporate responsibility. Instrumental, or economic, corporate social responsibility holds that corporations should engage in pro-social or ethical conduct only when doing so will improve the return on investment of the financiers of the organization. ${ }^{44}$ Proponents of this perspective are committed to the view that TNCs should meet human rights standards only when doing so generates more revenue than not meeting human rights standards. If violating human rights standards is more profitable, then from this perspective that is the obligation of TNC managers.

The shareholder primacy ideology has been soundly criticized by management and legal scholars, ${ }^{45}$ but it has received less explicit attention in the context of international business and human rights. ${ }^{46}$ One might think that a view that was defended by influential scholars would have a firm grounding in a well-developed theory of the legitimacy of corporate practices in a global economic system, but this is not the case.

\footnotetext{
42 Thomas M Jones and Will Felps, 'Shareholder Wealth Maximization and Social Welfare: A Utilitarian Critique' (2013) 23:2 Business Ethics Quarterly 207-38; Lynn A Stout, The Shareholder Value Myth: How Putting Shareholders First Harms Investors, Corporations, and the Public (San Francisco: Berrett-Koehler Publishers, 2012).

43 Denis G Arnold, 'Libertarian Theories of the Corporation and Global Capitalism' (2003) 48:2 Journal of Business Ethics $155-73$.

44 Abagail McWilliams and Donald S Siegel, 'Corporate Social Responsibility: A Theory of the Firm Perspective' (2001) 26:1 Academy of Management Review 117-27; Abagail McWilliams, Donald S Siegel and Patrick M Wright, 'Corporate Social Responsibility: Strategic Implications' (2006) 43:1 Journal of Management Studies 1-18. For criticism of this view see Jean-Pascal Gond, Guido Palazzo, and Kaushik Basu, 'Reconsidering Instrumental Corporate Social Responsibility through the Mafia Metaphor' (2009) 19:1 Business Ethics Quarterly 57-85.

45 Sumantra Ghoshal, 'Bad Management Theories are Destroying Good Management Practices' (2005) 4:1 Academy of Management Learning \& Education 75-91; Jones and Felps, note 42; Stout, note 42.

46 Florian Wettstein, 'CSR and the Debate on Business and Human Rights: Bridging the Great Divide' (2012) 22:4 Business Ethics Quarterly 739-70.
} 
Consider just two of the difficulties with the shareholder position as applied to the human rights context: faulty assumptions regarding institutional frameworks and the lack of democratic governments in many nations in which TNCs operate.

\section{Faulty Assumptions Regarding Institutional Frameworks}

The shareholder primacy ideology is grounded in a faulty interpretation of corporate law, namely, that the sole obligation of TNC executives and managers is to maximize economic value. Lynn Stout points out that, contrary to the shareholder primacy ideology, corporate law in the U.S. gives directors and executives wide discretion with regard to corporate objectives via the business judgment rule. ${ }^{47}$ In practice this entails that managers have the legal right to take into account the actions of their companies on other stakeholders and on society in general. Pressure from Wall Street analysts, major investors, and poorly-designed executive incentive structures can encourage a myopic focus on short term stock performance and disregard for social considerations such as human rights, but this is not a legal requirement and many U.S. companies are managed in a way that balances the interests of multiple stakeholders. In the United Kingdom, the revised Companies Act requires that directors take into account the interests of the company's employees, 'the impact of the company's operations on the community and the environment', the need to maintain 'a reputation for high standards of business conduct', and the need to act fairly. ${ }^{48}$ More generally, 15 of 27 member states of the European Union have national policy frameworks for promoting corporate social responsibility. The European Commission, the executive governing body of the European Union, has recommended that all member states implement such frameworks. ${ }^{49}$

Many of the nations in which TNCs conduct business lack important democratic institutions such as equal voting rights, multiple political parties, democratic elections, politically neutral militaries, and an independent judiciary. According to Freedom House, 36 per cent of nations, including China and Russia, are not electoral democracies. In addition, 56 per cent of the world's sovereign states and colonial units-home to 60 per cent of the world's population-lack civil or political freedom. ${ }^{50}$ The shareholder primacy view presumes the existence of electoral democracies, and the civil and political rights that facilitate political speech and activity, so that citizens can regulate business activity. ${ }^{51}$ The shareholder primacy view is inapplicable in other political contexts. However, international business is conducted in all nations and a theory of the firm that cannot provide guidance to companies operating in unfree or partially free nations can provide no guidance for TNCs operating in a global economy.

\footnotetext{
47 Stout, note 42.

48 United Kingdom, Companies Act 2006, sec 172(1).

49 European Union Commission, A Renewed EU Strategy 2011-14 for Corporate Social Responsibility (Brussels: EU Commission, 2011).

50 Freedom House, 'Freedom in the World' (2016), https://freedomhouse.org/report/freedom-world/freedom-world2016 (accessed 28 January 2016).

51 Arnold, note 43.
} 


\section{Regulatory and Governance Gaps}

In non-democratic nations, as well as in many electoral democracies, there are regulatory and governance gaps pertaining to business operations. A regulatory gap refers to a substantive lack of regulation regarding some type of business activity. In this context, the gaps we are concerned with are those that permit harm to human welfare (e.g., gaps in the protection of internationally recognized labour rights, or in environmental laws that protect water and air quality, or in financial regulations preventing usurious loans). Such gaps should be filled by regulations that better protect citizens from exploitation and the degradation of the environments in which they live. Many developing nations have such regulatory gaps that companies have historically utilized to advance profit maximization. ${ }^{52}$ Governance gaps involve institutional failures to enforce existing regulations regarding business activity or to create regulations intended to protect human rights. ${ }^{53}$ This may be the result of political turmoil, weak or corrupt governments, or a lack of institutional resources necessary to police and enforce existing regulations. Governance gaps are present in many developing nations and in Russia and former Soviet bloc nations. Governance gaps often prevent the enforcement of regulations intended to protect citizens from physical harm or deprivation and the degradation of the natural environments in which citizens live and upon which they depend upon for their livelihood.

TNCs exploit governance gaps when they or their suppliers violate local laws in their business operations with the knowledge that local authorities are unable or unwilling to adequately enforce existing regulations. The violation of local labour and environmental laws often results in human rights abuses such as forced labour, human trafficking, corporal punishment of workers, false imprisonment, discrimination, suppression of the freedom to organize, and death or injury as a result of poor working conditions or exposure to harmful environmental pollutants. A failure to adhere to host nation laws and regulations can result in costs savings, faster turn-around time for production orders, increased access to markets, or greater sales. Violation of the law may be routine and incorporated into the business strategy of a transnational company, or it might be the decision of one or more subsidiaries of a multinational company with a decentralized and nationally self-sufficient organizational structure, or it may be undertaken by suppliers who are not carefully monitored by a company.

It is difficult to assess how widespread the practice of violating host nation laws may be among transnational companies, their subsidiaries, and suppliers. Recently the United States Securities and Exchange Commission stepped up enforcement of the U.S. Foreign Corrupt Practices Act. Bribery is typically illegal in the host-nations where it takes place but governance gaps result in lax enforcement by authorities. Among the 60 companies that the U.S. Securities and Exchange Commission has taken enforcement actions against recently for corruption are U.S. based General Electric for corruption in Iraq; Eli Lily for corruption in Russia, Brazil, China, and Poland; Pfizer for corruption in

\footnotetext{
52 Ibid; Cragg (2009), note 27.

53 Human Rights Council, 'Promotion and Protection of Human Rights', E/CN.4/2006/97 (22 February 2006); Human Rights Council, 'Protect, Respect and Remedy: A Framework for Business and Human Rights', A/HRC/8/5 (7 April 2008).
} 
Bulgaria, China, Croatia, the Czech Republic, Kazakhstan, Russia, and Serbia; Johnson \& Johnson for corruption in Poland, Romania and Iraq; IBM for corruption in China; $\mathrm{KBR}$ and its former parent Halliburton for corruption in Nigeria; London-Based Diageo for corruption in India and Thailand; French-based Alcatel-Lucent for corruption in Costa Rica; and the German company Siemens for corruption in Indonesia. Corruption and bribery are unique in that the violation of host-nation laws also violates U.S. law (as well as the 2010 U.K. Bribery Act) providing an incentive for companies to maintain an active compliance and corruption prevention program. The violation of labour and environmental laws in host nations does not normally also violate U.S., U.K., or European Union laws and as a result companies have less incentive for compliance with these laws. As discussed above, there are also many political contexts in which regulatory gaps exist, where human rights violations are legally permitted and where TNCs human rights violations are not at the same time violations of the law.

The logic of the shareholder primacy perspective encourages the exploitation of regulatory and governance gaps. First, governance and regulatory gaps often exist in non-democratic nations where the shareholder primacy ideology is inapplicable because it is predicated on the existence of democratic governments where citizens freely determine business regulations through their elected representatives. ${ }^{54}$ Second, in developing nations that are also democracies, but with weak governance institutions, the relentless pursuit of profit advocated by the shareholder ideology implicitly advocates illegal activity when such activity is profitable and governments are unable to enforce existing regulations. Proponents of the shareholder primacy ideology have been conspicuously silent on the question of what obligations transnational companies have when, for example, labour and environmental laws go unenforced in developing nations. Gond, Palazzo, and Basu argue that that the logic of shareholder primacy and instrumental corporate responsibility is consistent with the institutional logic of the Italian mafia which has a similar focus on extreme profits and the exploitation of governance gaps. ${ }^{55}$

\section{B. Status Egalitarianism and State Obligations}

Nieh-hê Hsieh has recently argued that corporations should not be understood to have human rights obligations because, as private actors, corporations are not the proper type of institution to protect status egalitarianism in society. ${ }^{56} \mathrm{Hsieh}$ argues that if we take as central to human rights the ideal of status egalitarianism, ${ }^{57}$ then there is reason to reject assigning human rights obligations to MNEs and their managers' ${ }^{58}$ His discussion of status egalitarianism, or the equal standing of citizens, is derivative of the work of Allen Buchanan whose explicit focus is the international legal human rights system. Buchanan characterizes status egalitarianism as 'a robust commitment to affirming and protecting

\footnotetext{
Arnold, note 43.

Gond et al, note 44.

56 Nien-hê Hsieh, 'Should Business have Human Rights Obligations?' (2015) 14:2 Journal of Human Rights 218-36.

57 Buchanan (2013), note 30, 30.

58 Hsieh, note 56, 219, italics in original.
} 
the equal basic moral status of all individuals, 59 and he quite reasonably argues that status egalitarianism is an important 'aspect' of the international legal human rights system. ${ }^{60}$

Hsieh argues that TNCs do not have human rights obligations for two reasons. First, 'to assign human rights obligations to MNEs is to ask them to adopt a perspective of impartiality and equal treatment that seems not only overly demanding but also incompatible with what is required of private actors in the realm of economic activity' ${ }^{61}$ Oddly Hsieh does not argue for this claim or explain why impartiality and equal treatment of, say customers or employees is incompatible with economic activity. Second, Hsieh claims that status egalitarianism needs to be enforced by 'institutions at the level of society' and that:

by placing human rights obligations on [TNCs], in a sense the scope of status equality shrinks. That is, no longer are citizens understood to be members in equal standing in relation to one another but rather in equal standing in relation to others within the scope of activity of [TNCs]. ${ }^{62}$

Again, the argument is not precisely clear. Hsieh moves from the plausible claim that societal institutions are required to support status egalitarianism to the puzzling conclusion that when TNCs support the enforcement and protection of human rights standards, status equality 'shrinks'. Let us consider these claims in succession.

\section{Are Economic Actors Exempt from Human Rights Obligations?}

Hsieh claims that obligations of impartiality and equal treatment are incompatible with the economic activity of corporations. There are at least two ways of interpreting this claim. First, it might be interpreted as maintaining that firms do not have this obligation with respect to their employees, customers, and others with whom they interact because it is incompatible with the economic function of business. On this reading, Hsieh would seem to be committed to the position that TNCs have no obligation to avoid discrimination. For example, on this interpretation firms should be free to discriminate in hiring based on race, sex, or caste, they should be free to discriminate against women by paying men more than women for equal work, and they should be free to discriminate against the poor by requiring them to work overtime to earn subsistence wages and by neglecting their health and safety at work. Perhaps Hsieh would argue that this is only the case when it is lawful to do so, however, it remains unclear why the legal prohibition would constitute a reason for firms to refrain from discrimination if as economic actors they are not obligated to respect the protection of human rights by states as outlined in the Guiding Principles. In other words, Hsieh seems committed to the position that as economic actors firms have no obligations other than to maximize economic value. Hsieh does not explicitly embrace the shareholder primacy view and instrumental corporate responsibility, but it is difficult to understand how this position can be defended absent an appeal to some version of the shareholder primacy ideology. Nor is it

\footnotetext{
59 Buchanan (2013), note 30, 27, italics in original.

60 Ibid, 30.

61 Hsieh, note 56, 226.

62 Ibid.
} 
clear how Hsieh would respond to the arguments discussed previously in this article that have claimed direct, moral human rights obligations on the part of TNCs.

Alternatively Hsieh might be read as claiming that TNCs have no obligations to promote and protect status egalitarian values and practices in society at large. On this interpretation, Hsieh is interpreted as maintaining that TNCs should not be asked to take on a role analogous to nation states in ensuring that status egalitarian ideas are promoted and protected for all people globally. For example, TNCs should not be expected to ensure that all members of society meet basic social welfare standards. If this interpretation is correct, it is a puzzling criticism of corporate human rights obligations (both agentically grounded human rights obligations and obligations grounded in the work of the UN and ILO). The Guiding Principles, for example, were carefully designed specifically to avoid confusion about the roles of corporations versus states in the promotion and protection of human rights. More specifically, the Guiding Principles recognize: 'The role of business enterprises as specialized organs of society performing specialized functions, required to comply with all applicable laws and to respect human rights'. ${ }^{63}$ The Guiding Principles require that firms, 'Avoid causing or contributing to adverse human rights impacts through their own activities, and address such impacts when they occur' and 'Seek to prevent or mitigate adverse human rights impacts that are directly linked to their operations, products or services by their business relationships, even if they have not contributed to those impacts' ${ }^{64}$ There is no expectation that TNCs and other business enterprises take on a state-like role regarding human rights in the United Nations 'Protect, Respect and Remedy' Framework. It is true that some theorists defend a state-like role for corporations that is constrained only by the capacities of the firm, ${ }^{65}$ but that is neither the view articulated by the Guiding Principles nor by most scholars who have defended corporate human rights obligations. ${ }^{66}$

\section{Do TNC Human Rights Obligations 'Shrink' Equal Standing Among Persons?}

Hsieh's second claim is that when TNCs and other business enterprises fulfil human rights obligations 'status equality shrinks'. By this he appears to mean that by fulfilling human rights obligations TNCs diminish the standing of equality in society. But why should this be the case? No defenders of corporate human rights obligations maintain that TNCs and other business enterprises ought to supersede the role of the state in the promotion and protection of human rights, including those most closely linked to status egalitarianism. The 'worry' as expressed by Hsieh may have its most plausible articulation when applied to TNCs operating in nations where governance gaps are the most grievous. Under those circumstances the states fail to meet the expectations of the international legal human rights system with respect to the protection of status equality for its citizens. Hsieh's argument appears to be that if TNCs attempt to protect status

63 Human Rights Council, note 39, 1.

64 Ibid, 15, italics added.

65 Florian Wettstein, Multinational Corporations and Global Justice: Human Rights Obligations of a QuasiGovernmental Institution (Stanford, CA: Stanford University Press, 2009).

66 Arnold (2010), note 24; Bishop, note 17; Cragg (2004), note 27; Cragg (2009), note 27; Donaldson (1991), note 27; Kobrin, note 37. 
equality in their spheres of influence, they will diminish the standing of status equality beyond their sphere of influence. How should theorists and proponents of corporate human rights obligations respond?

Let us begin by noting that even under such circumstances the expectation is not that TNCs ensure status equality for everyone, or even status equality for those directly impacted by their operations, but instead the expectation is that they meet a more limited scope of obligations. In the international legal human rights system that is the focus of Buchanan's analysis (and hence Hsieh's) the explicit expectation of TNCs is that they 'avoid infringing on the human rights of others' and 'address adverse human rights impacts with which they are involved' ${ }^{67}$ In governance voids, where human rights are not protected by the state, status equality and respect for human rights more generally are already greatly diminished. If TNCs operating in such governance voids meet human rights obligations (e.g., the ILO conventions) doing so will enhance rather than diminish status equality, as it will expand the extent to which human rights are respected. Hsieh's position appears wedded to the old model of an individual-State dichotomy, and resistant to the multi-actor system associated with the emergence of a transnational world order populated by supranational organizations that is the basis of the new corporate human rights agenda. Indeed, Hsieh's position is inconsistent with that of Buchanan, whose conclusions regarding the current international legal human rights system include the idea that, 'In principle, there appears to be no barrier to modifying the system of international legal human rights' to hold 'non-state actors such as global corporations' legally accountable for human rights duties articulated in the Guiding Principles. ${ }^{68}$

The current multi-actor international system requires a different conceptualization of the moral division of labour than has been favoured by political philosophers historically. Typically, political philosophers have defended a conception of the basic structure of society between governments and individuals. Rawls' theory of justice includes a prototypical example of this dualist conception of the basic structure of society. ${ }^{69}$ From a Rawlsian perspective, corporations are mere associations of individuals like church congregations, local sports clubs, and book clubs. ${ }^{70}$ Hsieh's scholarship has focused on the application of Rawlsian political philosophy to problems in business ethics, so it is not surprising that he would embrace the same division of moral labour in society. ${ }^{71}$ An alternative conceptualization of the division of moral labour is needed for the existing multi-actor international economic, legal, and political system. TNCs should be conceptualized not as mere associations of individuals, but as organizations distinct from governments, willing and capable of exerting significant influence over governments but typically with allegiance to no government. Cragg has

\footnotetext{
67 Human Rights Council, note 39, 13.

68 Buchanan (2013), note 30, 284.

69 Rawls, note 30, 268-9.

70 For a critique of this conception of the basic structure of society, see Arnold (2013), note 24, 131-4. For a general critique of the use of Rawlsian theory in business ethics scholarship see Wayne Norman, 'Rawls on Markets and Corporate Governance' (2015) 25:1 Business Ethics Quarterly 29-64; Abraham Singer, 'There is no Rawlsian Theory of Corporate Governance' (2015) 25:1 Business Ethics Quarterly 65-92.

71 Nien-hê Hsieh, 'The Obligations of Transnational Corporations: Rawlsian Justice and the Duty of Assistance' (2004) 14:4 Business Ethics Quarterly 643-61; and Hsieh, 'Does Global Business have a Responsibility to Promote Just Institutions?' (2009) 19:1 Business Ethics Quarterly 251-73.
} 
persuasively argued that while TNCs have human rights obligations in the international system for similar reasons to nation states, this does not entail that they have the same human rights obligations. ${ }^{72}$ TNCs have direct and indirect impacts on the human rights of individuals wherever they operate. In a pluralistic account of the international system, TNCs are properly and legitimately held accountable for these impacts. Indeed, the primary way that firms can gain normative legitimacy when operating in nations with significant governance gaps is by meeting human rights obligations in their operations. ${ }^{73}$ By advocating a dualist basic structure for the international system, one in which corporations have no direct or indirect human rights obligations, Hsieh is arguing for a Westphalian model in a post-Westphalian era. ${ }^{74}$

\section{Conclusion}

We have seen that TNCs have the kind of ontological status necessary for moral agency and moral responsibility and that they are capable of ignoring human rights obligations or of integrating human rights protections into their international operations. It has been argued that there are compelling reasons to believe that TNCs have agentically grounded moral obligations to respect basic human rights and that there are also sound social contract based reasons for concluding that businesses have human rights obligations. The international legal system of human rights includes explicit expectations for TNCs to respect the international human rights regime, an obligation endorsed by mainstream business organizations as well as individual companies and by most national governments. Arguments against corporate human rights obligations have been shown to be unsupportable in the case of the shareholder primacy ideology, and obscure and inconsistent in the post-Westphalian era in the case of the status egalitarian objection. The arguments of this article are intended to facilitate movement away from a debate about whether TNCs have human rights obligations, so that attention might be focused on management strategies for implementing human rights standards and political and legal strategies for holding firms accountable for the violation of human rights obligations in their global operations.

\footnotetext{
Cragg (2009), note 27.

Cragg (2009), note 27; Donaldson (1991), note 27.

74 Kobrin, note 37; Santoro, note 36.
} 